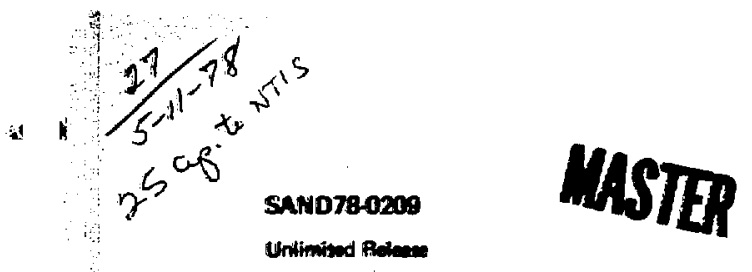

\title{
Distortion of Plasma Diagnostics by an Ambient Gas
}

Ly S. Peariman, OLF/DOE

it knimberian

\section{团 Sendia laboratoures}


Heund by Sundi Laboratories, operated for the It nised States Departiment of Enery by Sendia Corporation.

\section{notice}

This report wes prepered as an acount of work sponaored by Tha Unived States Government. Naither the United Stutes nor the Deparament of Eneng, nor any of their employees, nor any of thair contractors, mibcontractors, or thair employees.

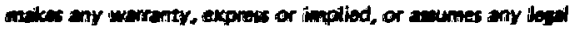
ti-bility or nemonstbility for the acouracy, completanos or

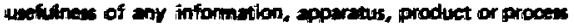

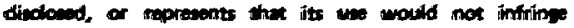
pritsenty awnod riphts.

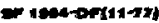


SAND-78-0209

Unlimited Release

Printed March 1978
Tha epan wa propated a an eroent of wot

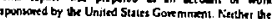

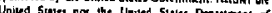

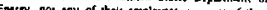

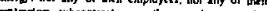
on

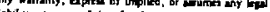

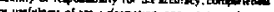

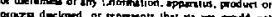

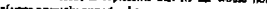

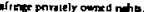

\title{
DISTORTION OF PLASMA DIAGNOSTICS BY AN AMBIENT GAS
}

\author{
Jay S Peerlman \\ Division of Laser Fusion \\ Depertment of Energy \\ Wieshington, D. C. \\ M. Ke1th Matzen \\ Laser Theory Division 5211 \\ Sandia Laboratories \\ Albuquerque, New Mexico 87115
}

\section{ABSTRACT}

The effect of vecuum chamber beckground gas on the ion measurements of a laser-produced, expanding plasma is studied over a wide range of background ges pressures. Experimental measurements are compared with calculations fram a coupled rete equation-hydrodyosmics code. The code is then used for a perametric study of the effect of beckground ges pressure on plasme diagnostic seacurements. Charge exchange 1s found to be an important process in our disenostics above vacuum chamber pressures of $10^{-5}$ Torr.

\section{Printed in the Unfted States of America}

Avallable from

Frational Technica? Information Service

U. S. Department of Commerce

5285 Port Royel Road

Sprlogrield, va 22161

Price: Printed Copy $\$ 3.50$; Maroflche $\$ 3.00$ 
W1th the 1nereased emphasis on evalmation of bigh temperature plavmas In rualon researeh and related arear, diagnostic techniques for character-

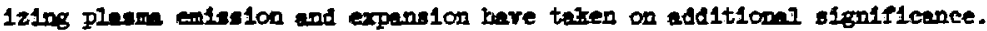
The correct interpretation of diegnontle measurements requires not only callbration with knom sources, but also cognizance of conditions in the experimental syatem and the diagnosties wich san signiflcantly affect the data. For example, secondery enssion, collector surface conditions, and eren the racuum chamber background presulue al1 may have a significant effect on the signel acquired with Faraday eup 10n dignoatics. The effect of seccodary emiselon has been eveluated previously for a varlety of Fareday cup configurations. ${ }^{1}$ An estimate of the erfect of vaeum chariber beciground gas on the 1on diagnost1es is important because the conflguration and ccoposition of the diagnosties in many target chambers 11mits the minfmum background gas presenures to the $10^{-5}$ to $10^{-4}$ Torr range. In this paper we will concentrate on the effect of seculno chamber background gas on Fareday cup and Thomson Farubola neasurements of $10 \mathrm{n}$ expanion from leser-created plasme. The platma were nearured under a variety of racuum chamber presmures. These experimental result were then used to nomallze a plasm kinet1ed code which ras coupled to a one-

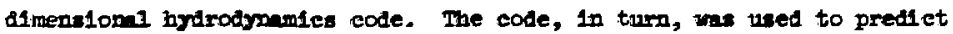
the impet of alde runge of backgnound pressures on plasma diagnostics. Tre experimental evaluation of beckground pressure effect employed a raglese lever operating at $2.7 \times 10^{14} \mathrm{w} / \mathrm{em}^{2}$ to irradete a thin rilo (explodis pusher) planer poljotgrem terget. The plame expanaton was

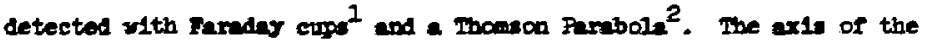


Thomson parabola wa norinl to the terget. The Thouson pariboll uses paraliel electric and morwetic flelds to aeparate lon sceording to their cherge/mass ratio end their energ. For CH plesme, this derlce perrifts unique 1dentification of all significant planon species. A schematic of the experiment is ahow in 14 gure 1. The Farader cups and the Themeon parabola were located et aldances of $30 \mathrm{~cm}$ and $100 \mathrm{~cm}$, reapectively, from the polystyrene tajget. The racuun preasure wa raried between $1 \times 20^{-5}$ Torr and $4.2 \times 10^{-1 / b}$ Torr of permitting air to bleed into the chamber and controling the puwing rate.

Ion current traces measured by Franday cup st two different pressured (uith all other conditions the sane) are shon in figures $2(a)$ and $2(b)$. Couparing the lower traces of $2(\mathrm{e})$ and $(\mathrm{b})$, in increase in the presenre from $1 \times 10^{-5}$ Torr to $4 \times 10^{-4}$ Torr Ieads to a reduction in eignal by about a factor of two. The Thomon parabole measuranente prorlde the capabil1ty for a mure deteiled interpretation of backroind gas eflect, since a rouch eralination of the species distribution an a nuction of gas pressure can be obtelned. Denultcaeter eraluations of Thomen parabola Fhotograph for three different backgrome preseures are given in flgures $3(\mathrm{e})-3(\mathrm{c})$. At the $4.6 \times 10^{-5}$ Dorr (21g. 3a), $c^{+1}$ through $c^{-5}$ are prenent Ith the coninent 1onization states being $\mathrm{c}^{+3}, \mathrm{c}^{+4}$ and $\mathrm{c}^{+5}$. When the presulure 1nereasen to $2.1 \times 10^{-4}$ Torr $(118.36), c^{+4}$ and $c^{+5}$ bave casentially disapieared and the dominent spectes are $c^{+1}, c^{+2}$ and $c^{+3}$. Incireacing the pranure st111 Iurther to $4.2 \times 10^{-4}$ Torr ( $148.3 c$ ), the dominant observed charese thetes are $\mathrm{c}^{+1}$ and $\mathrm{c}^{+2}$. The, a beiground preseure increase from $4 \times 10^{-5}$ to $4 \times 10^{-4}$ Iorr results in a change of the everage charge datected by the disponties $\operatorname{sron} \overline{\mathrm{z}} \sim 4$ to $\overline{\mathrm{z}}-1.25$. 
It 1. proposed that this decrease in observed $\overline{\mathrm{z}}$ can be related to charge exchange between the expanding plasm and the background gat in the vaculow chariber. To teat this concept, the charge exchange mechaniam was added to a plam ineties code wich correctly handlea lonization and recoubination rate procenses ${ }^{3}$. Nost of the charge exchange cross sections for the multiply lonlzed stated of carbon have not been experimentally determined over the energy range important in our plasme expansions. The cross section wich are avallable include the recent measurements of the charge exthenge of $c^{+1}$ with $x_{2}$ by Iocknood, Miller, and Hormmn ${ }^{4}$, the calculation of charge exchange of $\mathrm{c}^{+\mathrm{n}}$ with $\mathrm{H}$ by Olsen and Salop ${ }^{5}$, and the

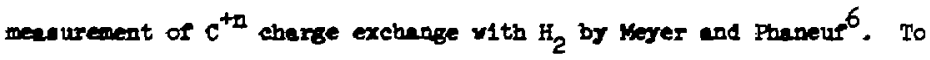
model the presence of aif in the vaculim chamber, we ansume the background gat to be $x_{2}$. Since there 18 no adequte scaling theory to estimate the $c^{+n}-I_{2}$ exose section fram the $c^{+n}-H$ and $c^{+n}-H_{2}$ eross sections, we

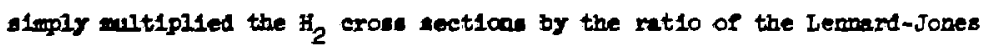
rigld aphere cross section for $\mathrm{I}_{2}$ and $\mathrm{H}_{2}(7)$ and estinated the $\mathrm{H}_{2}$ : $\mathrm{H}$ crose section ratio by compering results from References 5 and 6 at a relative reloelty of $3 \times 10^{8} \mathrm{~cm} / \mathrm{s}$. Valves of these wavired and estimated cross sections are abown in Table 1 for $c^{+n}$ enerdes froa 15.6 to $560 \mathrm{keV}$. Aul or the cross sections wed in thene extintes are ingle-ifectron copture

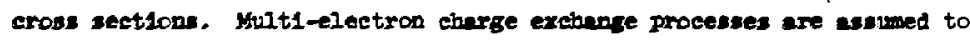
be untmportint. 8 We note that the date in Refarinces 5 and 6 suggents that for a relocity greater than $2 \times 10^{8} \mathrm{~cm} / \mathrm{a}$, the eingle electron capture cross soctions increase an the projectile charge stete inereases.

Twe comparison of the code rewults (eolid 11so) with the experimentel

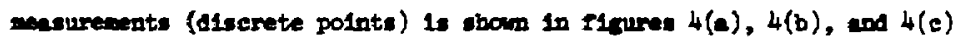


For a range of beckground get pressures. For 11 of these cangrisons the cross sections have been uniformily lecreased by a fector of 2 . The experimental points are deterninod quiltatirely by evalutiog the Thoman parabola traces as follows: an intense trace is assigned a mive of 1.0 , a trace just abore threabold corresponds to a rive of 0.1 , and traces wth intermediate intenaltied are acsioned vilues of 0.5 . A more detalled analysio of these traces is not marranted due to the soveral sources of non-11near respone in the Thomson parabole derles.9 For a prescure of $4 \times 10^{-5}$ Torr (118. 4a), the experinental and compatational trende are similar, but the ealculation predict that the arerage charge state is

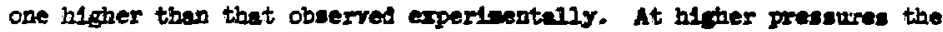

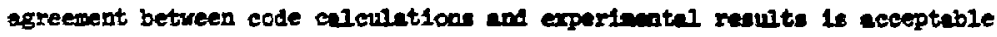
(rigures $4 \mathrm{~b}$ and $4 \mathrm{c}$ ). No attewpts sere med to improve agreement between experiment and theory by futher adjutwant of the charge axchunge cross section because of the qualitative nature of the andrals. With the charge exchange cross sections thu nomilized to the experimental results for $a$ rariety of beckground gas pressures, it is now poseible to study the effect of the vecum chanber conditions orer a muct rider range of

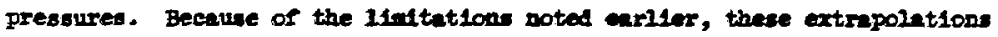
beyond the reault of the present experdents are interesting for the trends inich sey be cbererred.

The results of a broad mage paraweterization for a carbon plesm are

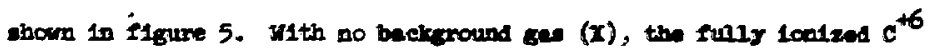

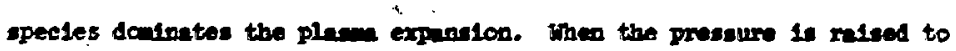
$1.2 \times 10^{-7}$ Torr $(0)$, rery 11ttle chenge is obserred. As the preseure Increases, rirat the concentration of $c^{45}$ beccmes roughly equal to the 
concentration of $c^{+6}\left(1.2 \times 10^{-5}\right.$ Torr, $\left.\square\right)$, and then the amount of $c^{+6}$ beccoses onl a smil percentage of the quent1t1es of $\mathrm{C}^{+3}$ and $\mathrm{C}^{+4}$ (1.5 $\times 10^{-4}$ Torr, (). F1m11y, et presaures above $2 \times 1 \mathrm{i}^{-4}$ Tarr, the lowest charge states dondnate the carbon 10n opecies distribution.

The 1macts of this trend are twofold. First, it 18 apparent that apecies distribution and $10 \mathrm{n}$ expanaion information thould be collected at yacuum pressures belou $10^{-5}$ Torr. Second, et higher pressures, $1 t$ appears that a sonifleant number of neutral atcas ere created through charge exchange. Thus the amalyals of date from the cherge detectors

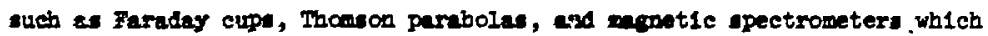
etteapt to obtain a plasm eneror balance through lon sollection can produce exroceous results.

In sumery, experiments have been carried out to determine the effect of velum phiber background gat on the mearumenent of the expansion from a lecer-produced plas:. The result, which indicete a igniflcant change in the apeciea dietribution, are used to normilie the charge

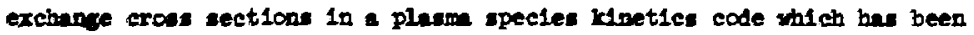

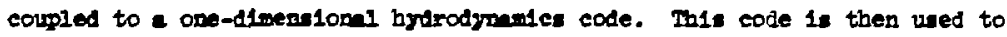
study the 1opect of beckground gas over a vide range of prestures. The cole predicts thet ubstantial diegnoutic errora vill oceur in our diagnostice for gu pressures sreater then $10^{-5}$ Tors. 


\section{ACWOXNTEDGPEHIS}

The euthors would Ilike to thenk Drs. B. Rlpin and R. Decote for early discussions on the importance of the charge exchenge sechantso, J. M. Horfman for alscusalons on the charge exchange crose sections, M. A. Falmer for his densitoneter work, and J. Levasek and $M$. D11lon for their technical asolstance. 


\section{FIGURE CAPTIOTS}

Figure 1. Thperinentel schemet1c. The Nd:glans laser strike the target et $17^{\circ}$ Iron the terget nomel. The Thonson parabole and Faradier vere $0^{\circ}$ and $17^{\circ}$, reepectively, from the terget noring.

F1gure 2. Farader cup currents at a vecuum chember background gea preesures of $1 \times 10^{-5}$ Torr (2a) and $4 \times 10^{-4}$ Torr (2b).

Figure 3. Deneitcater treced of the Thomeon parabola photographs for vacum chamber beckground gas preasured of $4.6 \times 10^{-5}(3 a)$, $2.1 \times 10^{-4}(3 b)$, and $4.2 \times 10^{-4}$ Torr (3c). The lower trace 10 each eqgure is $\mathrm{H}^{+}$.

F1gure 4. Comparison of the code result. (sol1d 11ne) with the experimental results (diverete points, see text for a description of their deterwination). Farts (a), (b), and (c) represent vacuum chamber background gas pressures of $4 \times 10^{-5}, 1.5 \times 10^{-4}$, and $4 \times 10^{-4}$ Torx, reopectively.

Fifure 5. Calenlation of tbe relative number of a partieular charge state of sarbon as a nunction of vaculom chamer background ant pressure. The points represent pressures of $0.0(x)$, $1.2 \times 10^{-7}(0), 1.2 \times 10^{-6}\left(\Delta, 1.2 \times 10^{-5}(\mathrm{C}), 1.5 \times 10^{-4}()\right.$, $2.6 \times 10^{-4}(\mathrm{D})$, and $5.1 \times 10^{-4}$ Torr $(7)$. 


\section{EXPERIMENTAL SCHEMATIC}

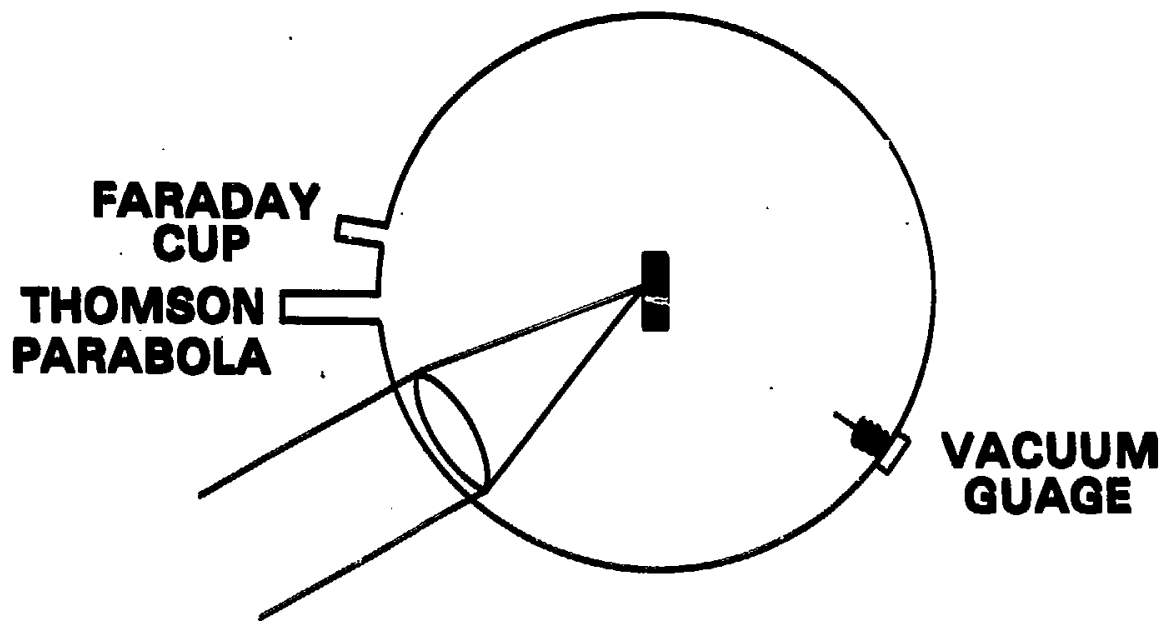

Fifure 1 


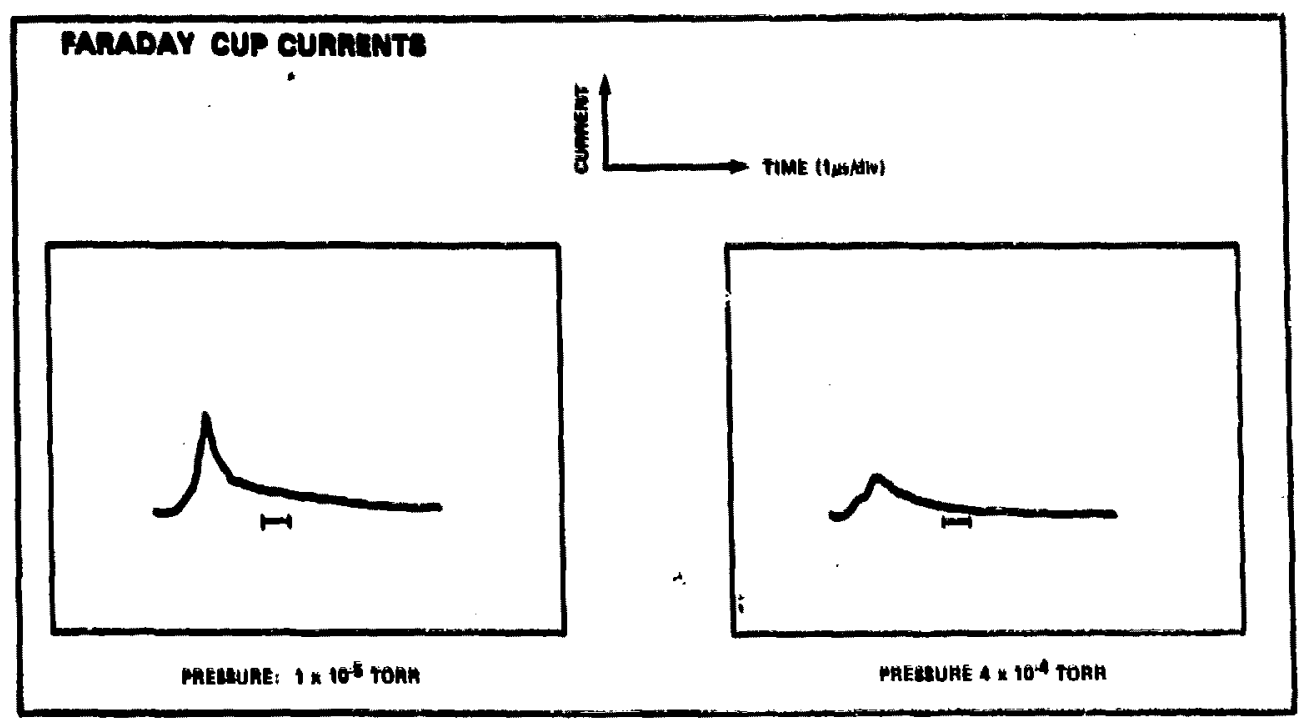

Figure 2 
$\pi$

$4.6 \times 10-5$ torr

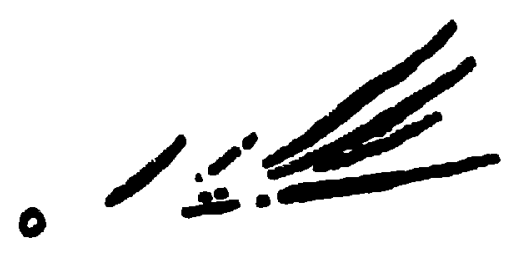

Pigure $3 \mathrm{a}$ 
$2.1 \times 10.4$ torr 
$4.2 \times 10-4$ torr

2

Figuie $3 c$ 


\section{COMPARISON OF CODE WITH EXPERIMENT}

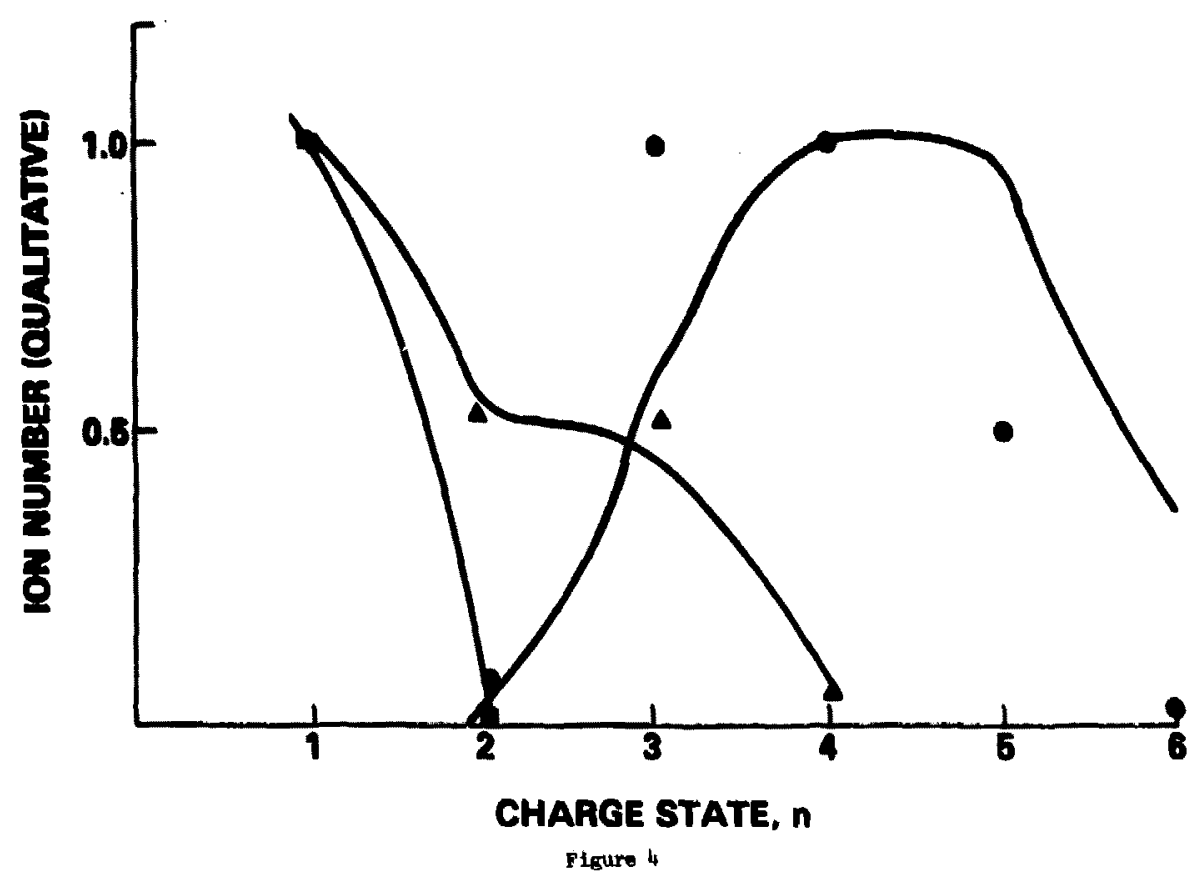




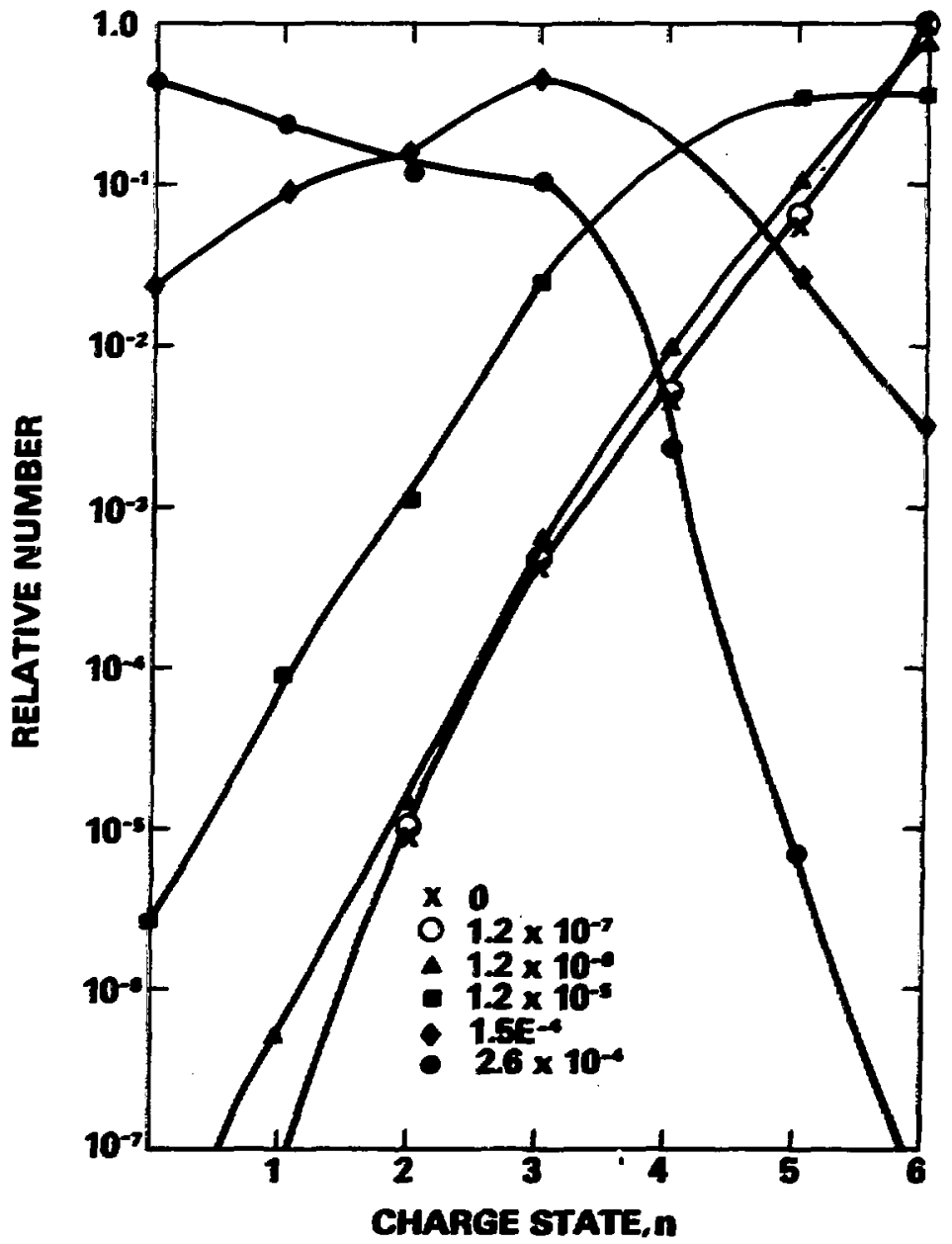

6 
Table 1. Charge exehange cross nection for $C^{+n}+A \rightarrow C^{+(n-1)}+A^{+}$, in units of $10^{-16}$ ?

\begin{tabular}{l|cccccc} 
E(zeV) & $1+0$ & $2+1^{(c)}$ & $3+2^{(c)}$ & $4+3$ & $5+4$ & $6+5^{(b)}$ \\
\hline 15.6 & $5.9^{(a)}$ & 20 & 5 & $20 *$ & $38 *$ & 89 \\
62.3 & $10.8^{(\mathrm{a})}$ & 15 & 10 & $20 *$ & $38 *$ & 89 \\
140.0 & $8.5^{(\mathrm{c})}$ & 11.3 & 15 & $20 *$ & $38^{*}$ & 68 \\
249.0 & $6.2^{(\mathrm{c})}$ & 9.4 & 17.6 & $20 *$ & $38 *$ & 57 \\
389.0 & $4.1^{(\mathrm{c})}$ & 7.9 & 17.6 & $20 *$ & $38 *$ & 49 \\
560.0 & $2.5^{(\mathrm{c})}$ & 6 & 12.5 & $20^{(\mathrm{c})}$ & $38^{(\mathrm{b})}$ & 44
\end{tabular}
(a) $\mathrm{c}^{\mathrm{tn}}+\mathrm{H}_{2}$ from Beference 4
(b) acled Iram Reference 5, $\mathrm{C}^{\text {tn }}+\mathrm{H}$
(c) scaled mon Reference $6, \mathrm{c}^{+\mathrm{n}}+\mathrm{H}_{2}$
(*) dete not ariliable, escuned constant as a fumetion of energy 
1. J. S Pearlman, Rey. Sc1. Instrue. 48, 1664 (1977).

2. J. H. Olsen, G. W. Kurm, and Z. D. Jones, J. Appl. Ftry. 44, 2275 (1973).

3. M. K. Matzen, Sandia Teehnical Report (to be piblished).

4. G. L. Lockood, G. H. N111er, J. N. Horfman, "charge Tranefer of $\mathrm{C}^{+}$, $\mathrm{S}^{+}$, and $\mathrm{O}^{+}$in $\mathrm{H}_{2}$ and $\mathrm{H}_{2}$," submitted for publication in Fyrs. Rer. A.

5. R. E. O1son and A. Salop, Fhys. Rey, A 16, 531 (1977); A. Selop and R. E. Olson, Fhys. Rer. A 16, 1811 (1977).

6. F. W. Meyer and R. A. Fhaneuf, "Charge Transfer Coll1sions of Mult1charged Carbon, Nitrogen end oxyen Ion with Atomic and volecular Hydrogen," presented at Topieal Conference on Atonic Procenses in High Tempernture Pladme, Knorrille, Tennessee, Feb. 16-18, 1977.

7. J. O. Hirschielder, C. P. Curtiss, and R. B. BIrd, Noleenlar Theory of Gaves and Iiqulds (W11er, Iew Yort, 1967), Fourth Printing, Append1x $I \rightarrow$.

8. A. 2. Olson, A. Salop, R. A. Fhanelif, and F. W. Yeyer, Furs. Rey. A 26, 2867 (1977).

9. M. A. Gualnon, T. J. Loekrood, H. H. DLIHan, L. E. Ruggles, "The Themson-Farabola Ion Amljzer", EMrD-78-0336, 1978. 